Article

\title{
Phytophthora austrocedri Elicitates Changes in Diterpene Profile of Austrocedrus chilensis
}

\author{
Verónica Rachel Olate ${ }^{1}$, María Laura Vélez ${ }^{2}$, Alina Greslebin ${ }^{3}$ \\ and Guillermo Schmeda-Hirschmann 1,*
}

1 Laboratorio de Química de Productos Naturales, Instituto de Química de Recursos Naturales, Universidad de Talca, Casilla 747, 3460000 Talca, Chile; E-Mail: volate@utalca.cl

2 CONICET-Área de Protección Forestal, Centro de Investigación y Extensión Forestal Andino Patagónico (CIEFAP), 9200 Esquel, Chubut, Argentina; E-Mail: mvelez@ciefap.org.ar

3 CONICET-Facultad de Ciencias Naturales, Universidad Nacional de la Patagonia, 9200 Esquel, Chubut, Argentina; E-Mail: agreslebin@unpata.edu.ar

* Author to whom correspondence should be addressed; E-Mail: schmeda@utalca.cl; Tel.: +56-71-2200288; Fax: +56-71-2201573.

Academic Editor: Derek J. McPhee

Received: 24 June 2015/ Accepted: 8 August 2015/ Published: 18 August 2015

\begin{abstract}
The populations of the Andean Cupressaceae Austrocedrus chilensis have been severely affected by a disease caused by the phytopathogenic fungus Phytophthora austrocedri. A study was undertaken to disclose changes in the resin composition of $P$. austrocedri-infected individuals, including naturally infected and artificially inoculated trees, compared with healthy A. chilensis trees. GC-MS and ${ }^{1} \mathrm{H}-\mathrm{NMR}$ studies showed a clear differentiation among healthy and infected resins, with the diterpene isopimara-8(9),15-dien-19-ol as a relevant constituent in resins from infected trees. The effect of resin fractions from $P$. austrocedri infected trees on the pathogen was assessed by measuring the mycelial growth in agar plates. The most active fractions from resin obtained from infected trees inhibited fungal growth by nearly $50 \%$ at $1 \mathrm{mg} / \mathrm{dish}\left(35.37 \mu \mathrm{g} / \mathrm{cm}^{2}\right)$. The main constituent in the active fractions were 18-hydroxymanool and the aldehyde torulosal. Both compounds are oxidation products of manool and can be a chemical response of the tree to the pathogen or be formed from the pathogen as a biotransformation product of manool by microbial oxidation. While the diterpene profiles from $A$. chilensis tree resins can easily differentiate healthy and $P$. austrocedri infected individuals, the possible conversion of manool to the antifungal derivatives 4 and 6 by the microorganism remains to be established.
\end{abstract}


Keywords: Phytophthora austrocedri; Austrocedrus chilensis; resin diterpenes; Cupressaceae

\section{Introduction}

The exudation of resins, a mixture of monoterpenes, sesquiterpenes, and diterpene resin acids, is a major part of the constitutive defense mechanisms in conifers. It has been reported that the resins protect against pathogenic agents and insects among other types of damage [1-4]. Resin acts by blocking wounds, repelling or flushing invader organisms out of the bark, and entrapping organisms by its sticky nature, inhibiting or even killing the invader due to its toxicity.

Resin can be also part of the inducible defense mechanisms, as in the case of traumatic resin ducts that are created de novo in response to wounds, insect damage or pathogenic fungi. The resin formed by traumatic ducts can be different than constitutive resin [5-7], and may be more toxic through changes in terpenoid components or addition of phenolics [7].

Whereas constitutive chemical defenses are generally non-selective with respect to the invader organism, inducible chemical defenses include both broad-spectrum and specific compounds. The resin of conifers contains mainly diterpenes [8-10]. Diterpenes in resins have been studied by NMR [11-13] and GC-MS $[10,14,15]$. The variability of the resin terpene composition in conifer species was investigated by Cool et al. (1991) [16] and Cool (1996) [17] in Fitzroya cupressoides. The diterpene composition of the conifer Austrocedrus chilensis was reported by Olate et al. (2011) [18] and seasonal variation in resin composition was also described [19]. There is no information about the variability on diterpene composition in this species under biotic or abiotic stress.

In the last few decades, the Cupressaceae Austrocedrus chilensis, known as "ciprés de la cordillera", has suffered a devastating disease known as "mal del ciprés" or, recently, as "Austrocedrus chilensis root disease" [20-22]. This disease is characterized by chlorosis, withering of the foliage, progressive defoliation and the death of the tree. It is caused by the pathogen Phytophthora austrocedri (Oomycota, Straminipila) [20-22].

There are few studies on antifungal activity of resins against Phytophthora spp. [23,24] in spite of the fact that it is a frequent response of trees to Phytophthora infection [25-29]. A. chilensis profusely produces resin associated with Phytophthora lesions in phloem. Resin-pockets are usually developed below bark in the advance of the Phytophthora lesion [22]. Whether this resin is a specific response to pathogen infection or simply a structural unspecific response is still unknown.

To elucidate this aspect, the composition of $A$. chilensis resin and its antifungal activity was investigated. The hypothesis was that the resin composition differs on healthy and Phytophthora-diseased trees. To test this hypothesis, resin profile from healthy, naturally infected and artificially infected trees was compared. Fractionated resin of affected trees was tested for antifungal activities.

The present work includes the profiling of resin from healthy and diseased trees of Austrocedrus chilensis and reports for the first time the effect of the A. chilensis resin on the growth of P. austrocedri. 


\section{Results and Discussion}

\subsection{Antifungal Activity}

The resin samples were compared by thin layer chromatography (TLC) to disclose similarities and differences among the different variables (healthy, natural infection and artificially inoculated trees). A representative resin from naturally infected trees (sample AR-15, Table 1) was selected for fractionation and antifungal testing. Preparative TLC afforded nine fractions, with most of the compounds eluting in the fractions Z1 to Z6 (Figure 1). A comparison of the means of fungal growth after 14 days inoculation is presented in Figure 2A. Growth inhibition assay of the different fractions was assessed by the radial growth of the fungus at 0.5 and $1 \mathrm{mg}$ of the fractions per dish, corresponding to 17.68 and $35.37 \mu \mathrm{g}$ sample $/ \mathrm{cm}^{2}$ (Figure 2B). At $1 \mathrm{mg}$ per dish $\left(35.37 \mu \mathrm{g}\right.$ sample $\left./ \mathrm{cm}^{2}\right)$, the most active fractions Z4 and Z6 inhibited fungal growth by $26.4 \%$ and $46.2 \%$, respectively while the effect at $0.5 \mathrm{mg}$ (17.68 $\mu$ g sample $/ \mathrm{cm}^{2}$ ) was $18.9 \%$ and $34.2 \%$, respectively. Fractions $\mathrm{Z} 4$ and Z6 significantly reduced P. austrocedri growth ( $p<0.001 v s$. ethanol control) (Figure 2). Fraction Z3 inhibited fungal growth by $13.2 \%$ and $7.1 \%$ at $0.5\left(17.68 \mu \mathrm{g}\right.$ sample $\left./ \mathrm{cm}^{2}\right)$ and $1 \mathrm{mg} / \mathrm{dish}\left(35.37 \mu \mathrm{g}\right.$ sample $\left./ \mathrm{cm}^{2}\right)$, respectively.

Table 1. Resin sample collection (November, 2011). Río Grande Valley, Parque Nacional Los Alerces, Provincia del Chubut, Argentina. F: Female, M: Male, U: Unknown.

\begin{tabular}{cccc}
\hline Tree & Gender & Sample Number & Observations \\
\hline A03 & F & AR-01 & Artificially inoculated \\
A07 & F & AR-02, AR-03, AR-04 & Artificially inoculated \\
A08 & M & AR-05, AR-06 & Healthy and artificially infected zones \\
A09 & F & AR-07, AR-08, AR-09 & Artificially inoculated \\
A06 & F & AR-10 & Artificially inoculated \\
A18 & U & AR-11, AR-12 & Artificially inoculated \\
A21 & U & AR-13 & Artificially inoculated \\
I01 & U & AR-14 & Infected, natural lesion \\
I02 & U & AR-15 & Infected, natural lesion $*$ \\
S01 & F & AR-16 & Healthy tree, naturally exuded resin \\
S02 & F & AR-17 & Healthy tree, naturally exuded resin \\
S03 & F & AR-18 & Healthy tree, naturally exuded resin \\
S04 & F & AR-19 & Healthy tree, naturally exuded resin \\
S05 & M & AR-20 & Healthy tree, naturally exuded resin \\
S06 & M & AR-21 & Healthy tree, naturally exuded resin \\
S07 & M & AR-22 & Healthy tree, naturally exuded resin \\
S08 & M & AR-23 & Healthy tree, naturally exuded resin \\
S09 & M & AR-24 & Healthy tree, naturally exuded resin \\
\hline
\end{tabular}

* Sample used for the antifungal activity study. 


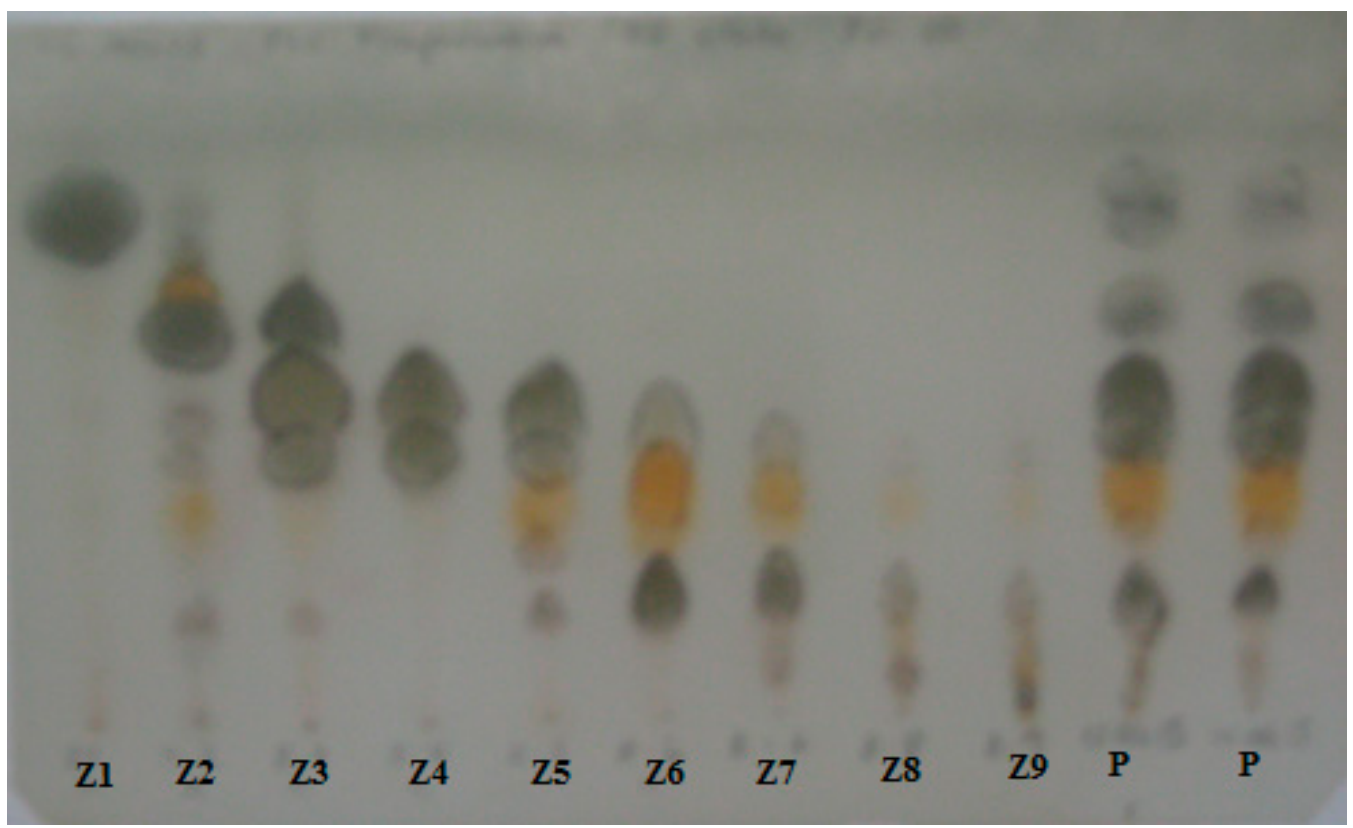

Figure 1. TLC analysis of the resin from $A$. chilensis tree naturally infected with $P$. austrocedri (P) (AR-15 sample) and the preparative TLC fractions Z1-Z9. Spots were revealed by spraying with $p$-anisaldehyde and heating. Silica gel, PE:EtOAc 8:2 (v:v).

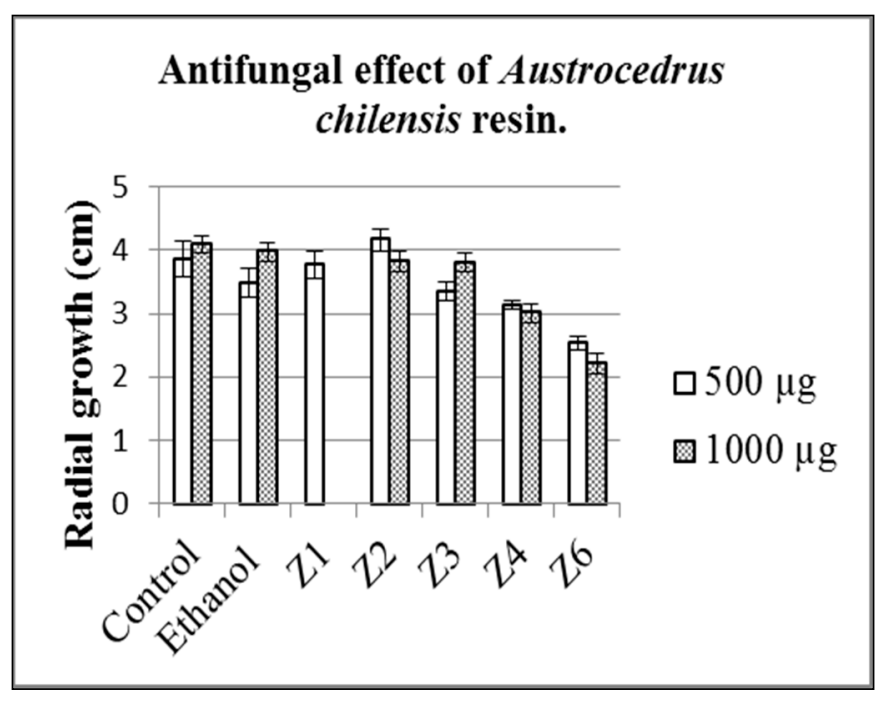

(A)

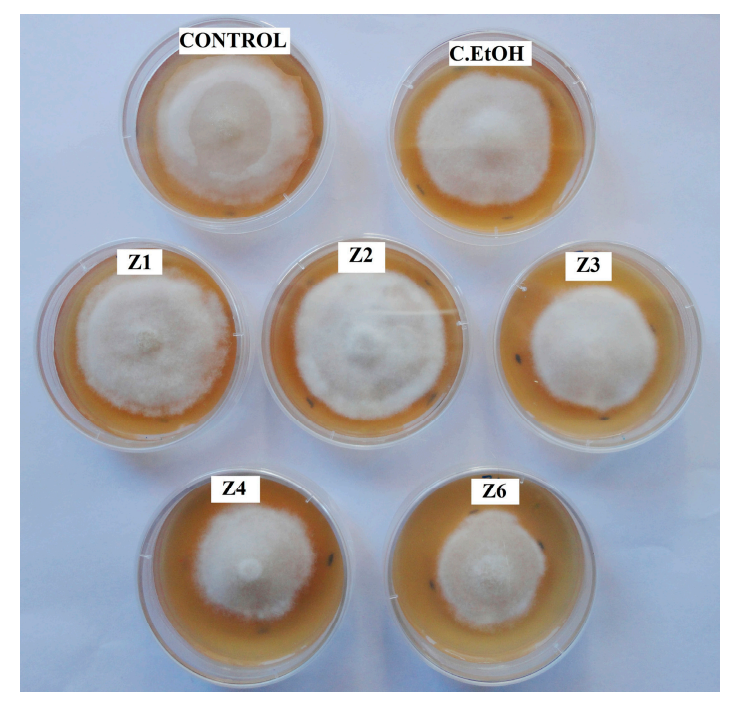

(B)

Figure 2. Antifungal effect of $A$. chilensis resin on P. austrocedri. (A) Graphic of the radial growth in agar dishes; (B) Growth inhibition assays for fungal growth. $500 \mu \mathrm{g}$ of each fraction were distributed in the dish giving a concentration of $17.68 \mu \mathrm{g}$ sample/ $\mathrm{cm}^{2}$. The controls are presented in the top of the image. Control: Untreated P. austrocedri; C. EtOH: Ethanol control. Z1-Z6: Tested resin fractions.

\subsection{Resin Profiling by GC-MS and ${ }^{1} H-N M R$}

The different resin samples, including healthy, naturally infected and $P$. austrocedri-inoculated male and female trees were compared by TLC (Figure 1), GC-MS (Figure 3) and ${ }^{1} \mathrm{H}-\mathrm{NMR}$. Figure 4 is showing the structures of compounds identified in resin from $A$. chilensis trees. The resin profiles from 
healthy trees were similar to those described by Olate et al. (2014) [19] for female and male individuals from a Chilean population of $A$. chilensis. However, naturally and artificially infected trees showed a distinctive and different profile with relevant changes in chemical composition. A peak at Rt $14.17 \mathrm{~min}$ was diagnostic for the infected resins. The mass fragmentation pattern of the compound is in agreement with the diterpene isopimara-8(9),15-dien-19-ol 1. Representative GC chromatograms of a healthy tree, a naturally infected and an artificially inoculated individual are shown in Figure 3.
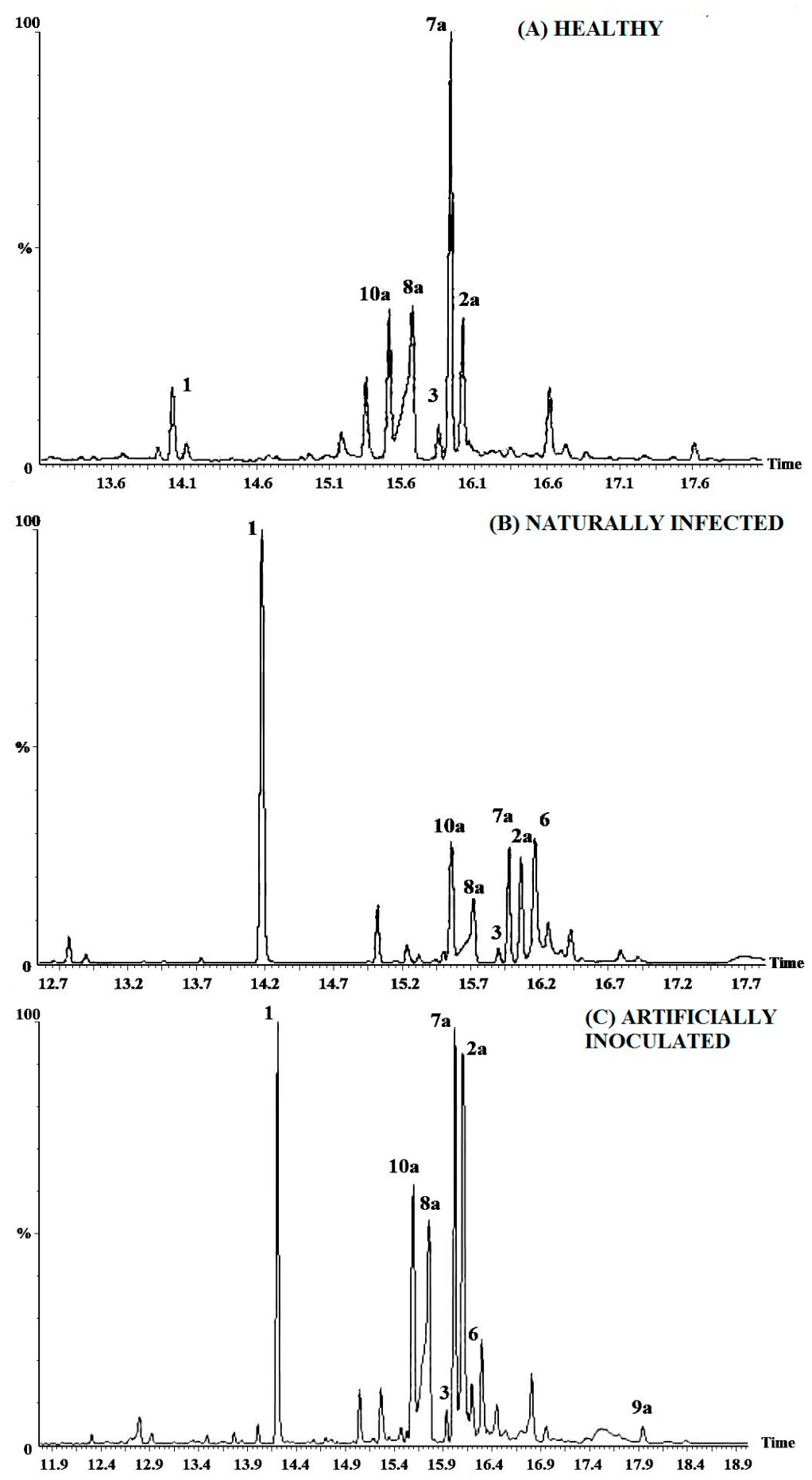

Figure 3. GC profiles of the Austrocedrus chilensis resin constituents from healthy and Phytophthora austrocedri-infected trees. (A) Healthy; (B) Naturally infected; (C) Artificially inoculated. 
<smiles>C=C[C@]1(C)CCC2=C(CCC3[C@@](C)(CO)CCC[C@@]23C)C1</smiles><smiles>[R][C@]1(C)CCC[C@]2(C)[C@@H](C/C=C(/C)C=C)C(=C)CC[C@@H]12</smiles>

$\mathrm{R}$

$7 \mathrm{COOH} E$-Communic acid

7a $\mathrm{COOCH}_{3}$<smiles>[R][C@]1(C)CCC[C@]2(C)c3ccc(C(C)C)cc3CC[C@H]12</smiles>

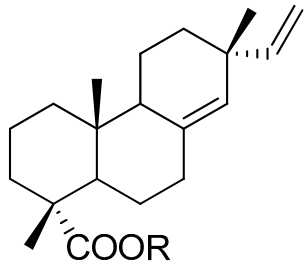

$\mathrm{R}$

$2 \mathrm{H}$ Sandaracopimaric acid 2a $\mathrm{CH}_{3}$

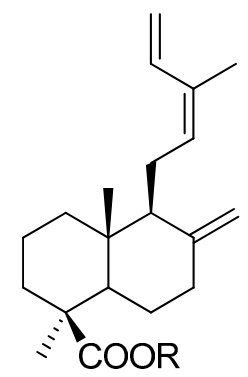

$\mathrm{R}$

8 H Z-Communic acid

8a $\quad \mathrm{CH}_{3}$

$\mathrm{R}_{1}$

$10 \mathrm{COOH}$

10a $\mathrm{COOCH}_{3}$

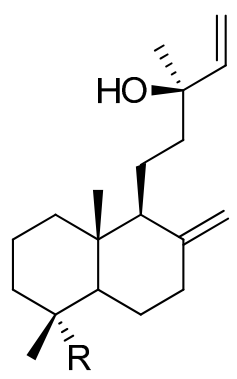

$\mathrm{R}$

$3 \mathrm{CH}_{3}$ Manool

$4 \mathrm{CH}_{2} \mathrm{OH}$

$5 \mathrm{CH}_{2} \mathrm{OAc}$

6 CHO Torulosal<smiles>[R]OC(=O)C1CCC(=C)[C@H](CC(=O)/C(C)=C/C)[C@@]1(C)CC</smiles>

$\mathrm{R}$

$9 \mathrm{H}$

9a $\mathrm{CH}_{3}$

18-hydroxymanool

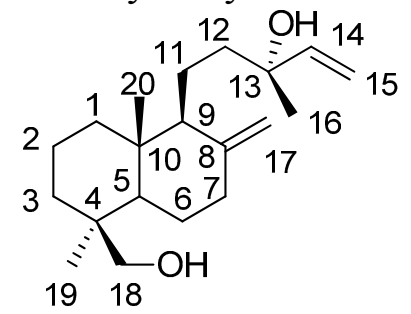

Figure 4. Structure of the compounds isolated and/or identified from the resin fractions of Austrocedrus chilensis trees naturally infected with Phytophthora austrocedri inhibiting radial growth of the phytopathogenic fungus.

The resin fractions showing inhibitory effect on the growth of $P$. austrocedri were analyzed by GC-MS and ${ }^{1} \mathrm{H}-\mathrm{NMR}$ to identify the constituents. In the GC chromatogram of $\mathrm{Z3}$, two main compounds were observed, eluting at $\mathrm{Rt}=14.17$ and $15.82 \mathrm{~min}$. The ${ }^{1} \mathrm{H}-\mathrm{NMR}$ analysis of the fraction showed the two main constituents, both sharing a common $-\mathrm{CH}=\mathrm{CH}_{2}$ and differing in the presence of a primary alcohol for the main compound and an exomethylene for the second diterpene. The spectra are in agreement with the diterpene $\mathbf{1}$ and manool 3, previously isolated from the tree resin [18]. The assignation of the diagnostic $\mathrm{H}$ signals is listed below.

Compound (Isopimara-8(9),15-dien-19-ol) (1): $5.77 \mathrm{dd}(17.5,10.8 \mathrm{~Hz}, \mathrm{H}-15), 4.91 \mathrm{dd}(11.0,1.7,1 \mathrm{H}$, H-16); 4.84 dd (17.5, 1.1, 1H, H-16'), 3.45 d (10.9, 1H, H-19); 3.18 d (10.9, 1H, H-19'), 1.01 s (3H, H-17), $0.98 \mathrm{~s}(3 \mathrm{H}, \mathrm{H}-18), 0.82 \mathrm{~s}(3 \mathrm{H}, \mathrm{H}-20)$. 
Compound (Manool) (3): $5.92 \mathrm{dd}(J=17.3,10.7,1 \mathrm{H}, \mathrm{H}-14) ; 5.22 \mathrm{dd}(17.4,1.1,1 \mathrm{H}, \mathrm{H}-15) ; 5.06 \mathrm{dd}$ $\left(10.7,1.1,1 \mathrm{H}, \mathrm{H}-15^{\prime}\right), 4.83 \mathrm{~d}(1.3,1 \mathrm{H}, \mathrm{H}-17)$; 4.53 brs $\left(1 \mathrm{H}, \mathrm{H}-17^{\prime}\right), 1.29 \mathrm{~s}(3 \mathrm{H}, \mathrm{H}-16), 0.88 \mathrm{~s}(3 \mathrm{H}$, H-19), 0.82 s (3H, H-20).

The fraction Z4-5 showed in the ${ }^{1} \mathrm{H}-\mathrm{NMR}$ spectrum an aldehyde $\mathrm{H}$ at $\delta 9.67 \mathrm{ppm}$, assignable to the main constituent as well as the $-\mathrm{CH}=\mathrm{CH}_{2}$ side chain, an exomethylene and three methyl singlets at $\delta 1.20,0.94$ and $0.49 \mathrm{ppm}$, compatible with torulosal 6. Several minor compounds also occurs in the fraction, including the isomers $E$-communic acid 7 and $Z$-communic acid $\mathbf{8}$ as well as the minor components $\mathbf{1}, \mathbf{5}$, and $\mathbf{9}$, identified by comparison with literature [18]. GC-MS analysis showed a main compound at $\mathrm{Rt}=16.16 \mathrm{~min}$., identified as torulosal 6, $E$-communic acid methyl ester $7 \mathbf{a}(\mathrm{Rt}=15.97 \mathrm{~min}$, $m / z=316)$; Z-communic acid methyl ester $8 \mathbf{a}(\mathrm{Rt}=15.71 \mathrm{~min}, \mathrm{~m} / z=316)$ and 12-oxolabda-8(17), $13 E$-dien-19 oic acid methyl ester 9a $(\mathrm{Rt}=17.89 \mathrm{~min}, \mathrm{~m} / \mathrm{z}=332)$, all of them in agreement with the literature [18,19].

The fraction Z6-7 presented in the GC-MS chromatogram a main compound $(>90 \%)$ at $\mathrm{Rt}=17.13 \mathrm{~min}$. With a molpeak of $m / z 288$, in agreement with the consecutive loss of two molecules of water from the diterpene 8(17),14-labdadien-13,18-diol (18-hydroxymanool) 4, reported from A. chilensis resin [18]. Two additional minor compounds were detected and identified as dehydroabietic acid methyl ester 10a $(\mathrm{Rt}=15.54 \mathrm{~min}, \mathrm{~m} / \mathrm{z}=316)$ and sandaracopimaric acid methyl ester $\mathbf{2 a}(\mathrm{Rt}=16.06 \mathrm{~min}, \mathrm{~m} / \mathrm{z}=316)$. The ${ }^{1} \mathrm{H}-\mathrm{NMR}$ spectrum of the fraction showed a main constituent with a monosubstituted double bond $(5.91 \mathrm{dd}, J=17.3,10.7 ; 5.20 \mathrm{dd}, J=17.4,1.1 ; 5.05 \mathrm{dd}, J=10.8,1.1 \mathrm{~Hz})$, a exomethylene $(\delta 4.82 \mathrm{~s}$, $4.52 \mathrm{~s})$ and a primary alcohol $(3.76 \mathrm{~d}, J=10.9$ and $3.38 \mathrm{~d}, 10.9 \mathrm{~Hz})$. Three methyl singlets at $\delta 1.28$, 0.98 and $0.65 \mathrm{ppm}$ further support the assignation of a diterpene skeleton with a tertiary alcohol function, in agreement with 18-hydroxymanool 4. The diagnostic ${ }^{1} \mathrm{H}-\mathrm{NMR}$ signals and the ${ }^{13} \mathrm{C}-\mathrm{NMR}$ spectral data of the compound are listed below.

Compound (18-Hydroxymanool) (4): ${ }^{1} \mathrm{H}-\mathrm{NMR}$ (400 MHz, $\mathrm{CDCl}_{3}, \delta$-values, $J$ in $\left.\mathrm{Hz}\right): 5.91 \mathrm{dd}(J=17.3$, 10.7, 1H, H-14); 5.20 dd (17.4, 1.1, 1H, H-15); 5.05 dd (10.8, 1.1, 1H, H-15'), 4.82 s (1H, H-17); 4.52 s (1H, H-17'), 3.76 d (10.9, 1H, H-18); 3.38 d (10.9, 1H, H-18'), 1.28 s (3H, H-16), 0.98 s (3H, H-19), $0.65 \mathrm{~s}(3 \mathrm{H}, \mathrm{H}-20) .{ }^{13} \mathrm{C}-\mathrm{NMR}\left(100 \mathrm{MHz}, \mathrm{CDCl}_{3}, \delta\right.$-values): $148.10 \mathrm{~s}, 145.19 \mathrm{~d}, 111.61 \mathrm{t}, 106.78 \mathrm{t}$, $73.59 \mathrm{~s}, 64.70 \mathrm{t}, 57.40 \mathrm{~d}, 56.34 \mathrm{~d}, 41.31$ t, 39.73, 38.97, 38.81, 38.63, 35.40, 27.47, 27.15, 24.39, $18.98,17.81,15.27$ q. ROESY experiments shows correlation of the methyl group at $\delta 0.64$ with the $-\mathrm{CH}_{2} \mathrm{OH}$ protons at $\delta 3.34$ and $3.72 \mathrm{ppm}$.

The fractions Z3, Z4-5 and Z6-7, obtained by preparative TLC of the resin from A. chilensis trees infected with $P$. austrocedri accounts for $15.0 \%, 28.3 \%$ and $19.4 \%$, respectively, from the total resin constituents. The most active fraction Z6-7 contains mainly 18-hydroxymanool $\mathbf{4}$ with $\mathbf{2}$ and $\mathbf{1 0}$ as minor constituents. Fractions Z4-5 yielded the aldehyde torulosal 6 as main compound with 1, 5, 7-9 as additional minor components. The less active fraction Z3 contained $\mathbf{1}$ as main compound, the alcohol 3 and the aldehyde 6 as other constituents. Mass spectra of the compounds 1, 2a, 3, 4, 6, 7a, 8a, 9a and 10a are shown in Figure 5. The fragmentation patterns were described in a previous work [18]. 

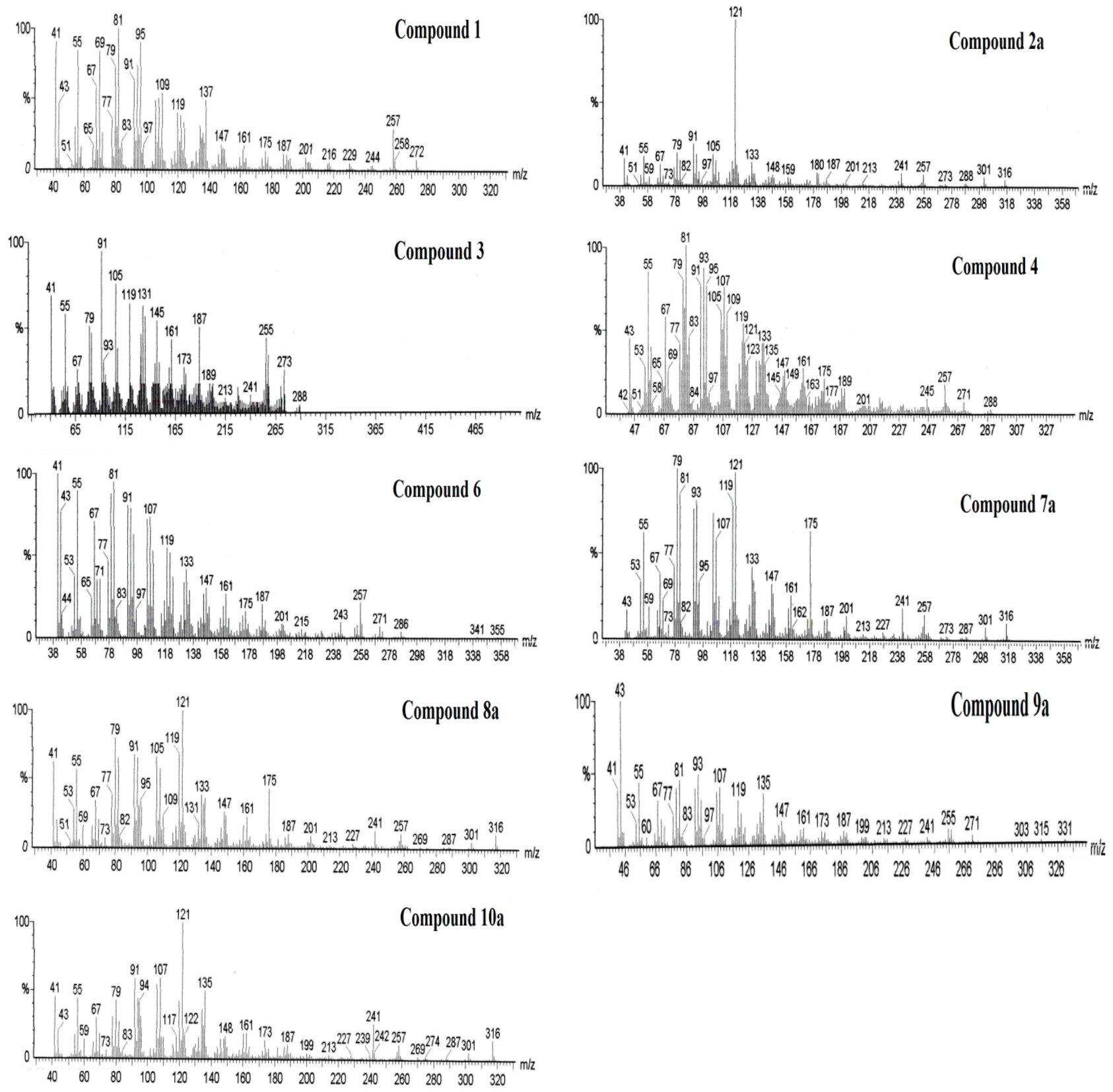

Figure 5. Mass spectra of the compounds 1, 2a, 3, 4, 6, 7a, 8a, 9a and 10a identified from the resin fractions of Austrocedrus chilensis trees inhibiting radial growth of the phytopathogenic oomycete Phytophthora austrocedri.

Production of differential resins in response to wounds, insect attack or fungal invasion has been reported [6,7,30], as well as the antifungal activity of these "defense-response resins" [2]. A four-fold increase of diterpenoids content was found in induced resin of inner bark of Picea spp. [6,7], the highest increment was observed in manoyl oxide [7].

Antifungal activity in conifers has been reported in Taxodium distichum cones, which contain mainly abietane-type diterpenes [31]. Sandaracopimarinol and ferruginol from extracts of Cryptomeria japonica were considered the most active constituents against phytopathogenic microorganisms (Fusarium oxysporum, Phytophthora capsici, Phytium splendens and Ralstonia solanacearum) [32]. Inhibitory action of volatile components of Pinus spp. oleoresins on Phytophthora spp. has been shown by Bunny 
and Tippet (1988) [23]. Previous work on induced resins have demonstrated that this resin with differential composition is produced de novo in traumatic resin ducts formed as a response to injury [5,6]. Thus, it would be of interest to investigate the possible presence of this kind of ducts in A. chilensis tissues.

The chemical composition of resins from healthy A. chilensis trees compared with that of $P$. austrocedri-infected individuals, including naturally infected and artificially inoculated trees showed a clear difference (Figure 3), with a diagnostic peak of compound $\mathbf{1}$ for the resins of infected trees. The fraction containing this compound as main constituent showed a slight inhibitory growth effect on P. austrocedri. The main component of the most active resin fraction Z6-7, is the C-18 oxidized product of manool, 18-hydroxymanool 4. The fraction inhibited growth of $P$. austrocedri by $34.2 \%$ at $0.5 \mathrm{mg} / \mathrm{dish}$ $\left(17.68 \mu \mathrm{g}\right.$ sample $\left./ \mathrm{cm}^{2}\right)$ and by $46.2 \%$ at $1 \mathrm{mg} / \mathrm{dish}\left(35.37 \mu \mathrm{g}\right.$ sample/ $\left.\mathrm{cm}^{2}\right)$, respectively. Manool was reported as having toxicity towards the brine shrimp and cytotoxic effects [33]. The compound showed antibacterial activity against Staphylococcus aureus and Stenotrophomonas maltophilia, antifungal effect against Candida albicans and cytostatic activity on human cancer cells [34]. The role of this compound on the defense strategy of $A$. chilensis to P. austrocedri infection deserves further studies.

The compound 4 can be further oxidized to the aldehyde 6 (torulosal) found as the major constituent of the Z4-5 fraction. The results suggest that different oxidation products from the diterpene manool play a role in the antifungal effect of the resin. Further studies should be carried out to disclose if the oxidation of manool is a host response or if the derivatives are formed via microbial oxidation (biotransformation) of the parent diterpene. Aranda et al. (1999) [35] reported the oxidation of manool by Mucor plumbeus to the 18-hydroxy derivative as well as several product of fungal bioconversion of labdane diterpenes. A comprehensive review of biotransformations of di-, triterpenes, steroids and other natural products has been summarized by Asakawa and Noma (2010) [36]. While the chemical profiles from $A$. chilensis tree resins can easily differentiate healthy and $P$. austrocedri infected individuals, the possible convertion of manool to the antifungal derivatives $\mathbf{4}$ and $\mathbf{6}$ by the microorganism remain to be established.

\section{Experimental Section}

\subsection{Plant Material}

Resin from phloem of male and female $A$. chilensis trees, including healthy and $P$. austrocedri-diseased trees was collected. To further confirm possible changes in resin composition associated with the fungal infection, resin from artificially inoculated P. austrocedri individuals (controlled conditions) were also included in the study. Trees were located in the Los Alerces National Park and the 16 de Octubre Valley, Chubut Province, Argentina (Figure 6). The resins were stored in glass containers, hermetically closed until analysis. The origin, sex and observations on the samples are summarized in Table 1.

\subsection{General Procedures}

All solvents used in chromatographical procedures were previously distilled. Pre-coated silica gel plates (Merck, Darmstadt, Germany, Kieselgel 60 F 254, $0.25 \mathrm{~mm}$ ) were used for TLC. TLC spots were visualized by spraying the chromatograms with $p$-anisaldehyde/ethanol/acetic acid/ $\mathrm{H}_{2} \mathrm{SO}_{4}(2: 170: 20: 10$ $v / v$ ) and heating at $110^{\circ} \mathrm{C}$ for $3 \mathrm{~min}$. 

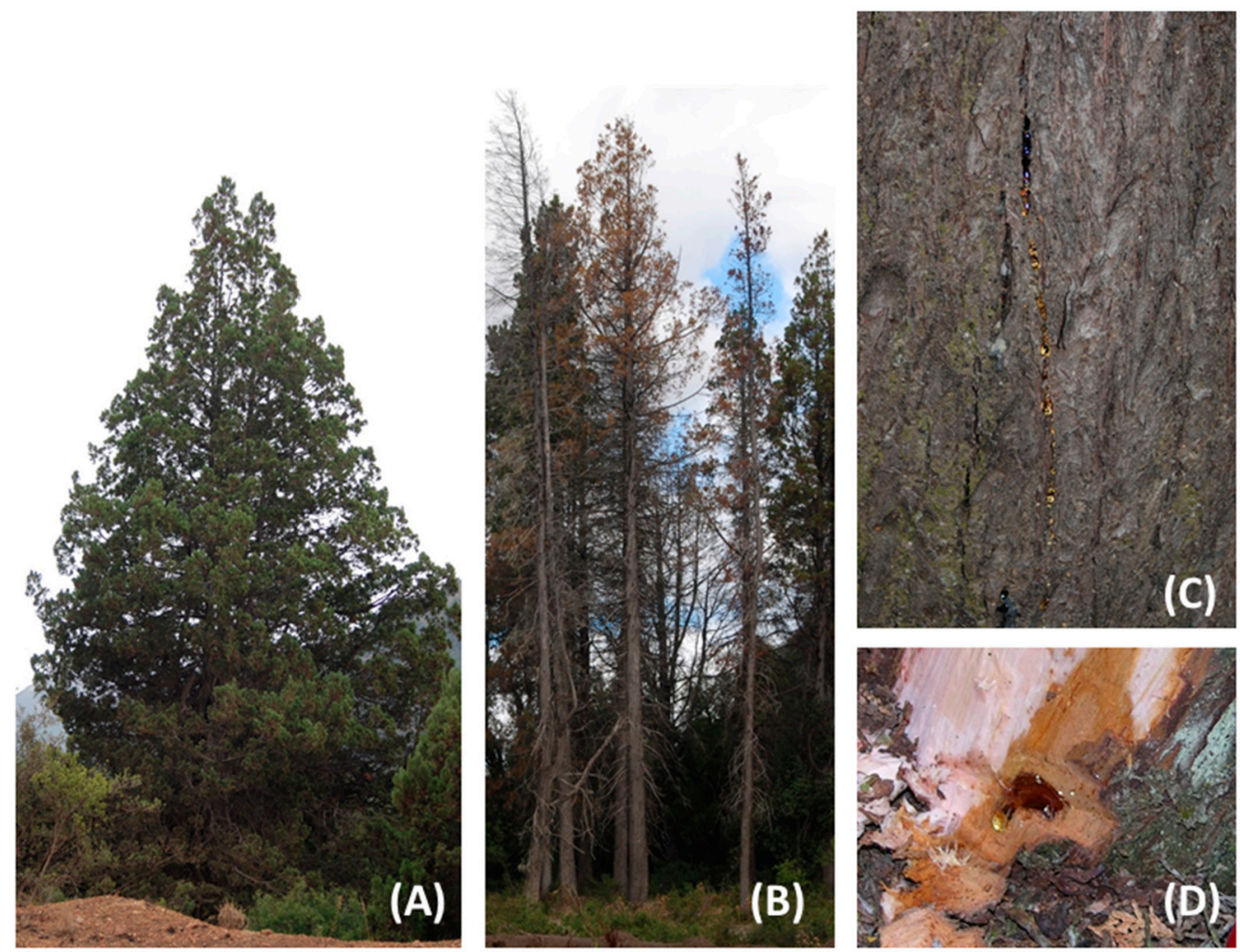

Figure 6. (A) Healthy Austrocedrus chilensis tree showing no symptoms of Phytophthora austrocedri infection; (B) Diseased Austrocedrus chilensis tree infected with Phytophthora austrocedri; (C) Resin exudates on bark of the tree base; (D) Detail of a resin pocket associated to a $P$. austrocedri lesion. Source: (A-C): Alina Greslebin; (D): Everett M. Hansen.

\subsection{Resin Analysis by TLC and Isolation of the Resin Constituents}

The composition of the different resin samples was first assessed by analytical TLC using silica gel as stationary phase and PE:EtOAc 80:20 ( $v / v)$ as eluent. The spots were visualized under UV light and revealed with $p$-anisaldehyde reagent and heating until development of colors. After TLC comparison, representative samples of the resin of male and female trees, including healthy, naturally infected and inoculated individuals were selected for GC-MS and NMR studies.

A representative sample from a diseased individual was selected for the preparative isolation of the constituents and antifungal-guided identification of the resin bioactives. The sample (400 mg) was separated by preparative TLC (silica gel, PE:EtOAc 80:20 v/v) in nine different zones, according to the Rf values and visualization under UV light. The bands were scraped off, extracted with ethyl acetate, filtered and taken to dryness to afford the fraction Z1 to Z9. Fractions Z4 and Z5 showing a similar composition were pooled as well as fractions Z6 and Z7. Fractions Z8 and Z9 contained mainly degraded products and were not further investigated. The fractions were assessed for activity against P. austrocedri and analyzed by GC-MS (as methyl esters) and ${ }^{1} \mathrm{H}-\mathrm{NMR}$. The compounds/fractions were stored in closed glass containers until the antifungal assays. 


\subsection{Antifungal Activity Assays}

The fractions obtained by preparative TLC of the sample were evaluated as antifungal agents against Phytophthora austrocedri. The assays were performed with 0.5 and $1.0 \mathrm{mg}$ fraction per Petri dish (60 mm, surface area: $28.27 \mathrm{~cm}^{2}$ ) using tomato agar as culture medium. The obtained fractions were dissolved in $25 \mu \mathrm{L}$ ethanol (Molecular Biology grade) and spread in the surface of sterile dishes containing the culture medium. The liquid was distributed uniformly with a triangular handle. The Petri dish surface was $28.27 \mathrm{~cm}^{2}$. Therefore, the 500 and $1000 \mu \mathrm{g} /$ dish are about 17.68 and $35.37 \mu \mathrm{g}$ fraction/ $/ \mathrm{cm}^{2}$, respectively. After drying the plates, a $5 \mathrm{~mm}$ plug from the margin of an actively growing colony of Phytophthora austrocedri was fixed in the central part of the agar. The plates were sealed and incubated at $15{ }^{\circ} \mathrm{C}$ in the dark. The radial growth of the pathogen was measured after 14 days. Treatments and the respective controls (solvent control: ethanol and untreated control) were done by quintuplicated. ANOVA was used to compare mean growth rates. Post hoc Tukey test were used for multiple comparisons of groups according to normality and homogenity of variance based on the Levene test (SPSS Statistics 17.0).

\subsection{GC-MS Analysis}

The resin samples were dissolved in anhydrous chloroform and treated with diazomethane in diethyl ether to obtain the methyl esters of carboxylic acids for analysis. The derivatized resins were dissolved in dichloromethane and $1 \mu \mathrm{L}$ was injected in the GC-MS apparatus for analysis. The method used was described in Olate et al. (2014) [19]. Equipment: Perkin Elmer Turbo Mass (Perkin-Elmer Corporation, Norwalk, CT, USA). Column: fused silica capillary column, SP-2330 (Supelco, St. Louis, MO, USA), $30 \mathrm{~m} \times 0.25 \mu \mathrm{m}$. Carrier: He, split flow $50.0 \mathrm{~mL} / \mathrm{min}$, initial set point: 20.0 PSIG. Oven program: total run time: $66 \mathrm{~min}$, initial temperature: $100{ }^{\circ} \mathrm{C}$, initial hold: $1.00 \mathrm{~min}$, Ramp: $10.0{ }^{\circ} \mathrm{C} / \mathrm{min}$ to $250{ }^{\circ} \mathrm{C}$, hold for 50.00 min. Injection volume: $1 \mu \mathrm{L}$. Compounds were characterized by electron-ionization (EI) mass spectra. Retention time (Rt, min) and MS fragmentation patterns of the known compounds were compared with literature (Olate et al., 2011, 2014) [18,19].

\section{6. ${ }^{1} H-N M R$ Analysis}

All NMR experiments were performed on a Bruker Avance 400 NMR spectrometer (Bruker BioSpin GmbH, Rheinstetten, Germany) equipped with a $5 \mathrm{~mm}$ inverse detection z-gradient probe. The ${ }^{1} \mathrm{H}$ spectra were measured at $400 \mathrm{MHz}$ at room temperature $\left(20^{\circ} \mathrm{C}\right)$ using $\mathrm{CDCl}_{3}$ as solvent. Chemical shifts are given on the $\delta$ scale and were referenced to residual $\mathrm{CHCl}_{3}$ at $7.25 \mathrm{ppm}$. One-dimensional ${ }^{1} \mathrm{H}$ spectra were acquired under standard conditions. Additional experiments for structural elucidation included ${ }^{13} \mathrm{C}-\mathrm{NMR}$, Distortionless Enhancement of NMR signals by Polarization Transfer (DEPT), Rotating frame Overhauser Effect Spectroscopy (ROESY) for the main compound from the fraction most active against $P$. austrocedri.

\section{Conclusions}

In this work, the changes in the diterpene composition of A. chilensis resin in the presence of the phytopathogenic fungus Phytophthora austrocedri were studied. The diterpene composition of resins from naturally and artificially infected trees was compared with resins from healthy individuals. The 
resin profiles were studied by GC-MS and H-NMR techniques. Resins from P. austrocedri infected trees showed relevant differences in its diterpene profiles in comparison with resin from healthy trees. The effect of resin from $P$. austrocedri infected trees on the growth of this pathogen was evaluated in vitro, using different resin fractions obtained by chromatographic means. The resin from $A$. chilensis taken from an infected tree exposed an interesting antifungal effect evaluated as the inhibition of mycelial growth in agar plates. The most active resin fractions contained 18-hydroxymanool and torulosal as the main constituents. These compounds are oxidation products of manool, probably produced by the tree as a chemical response against the fungal infection or formed by the pathogen as a biotransformation product.

The differences in the diterpene resin composition due to $P$. austrocedri infection were established in this work. However, the possible microbial conversion of manool to its oxidized derivatives requires further investigation.

\section{Acknowledgments}

V.R.O. thanks the Universidad de Talca for a doctoral grant. We are indebted to FONDECYT grant 1120096 and FONDECYT 1085306 for financial support. Financial support of ANPCyT-FONCYT, PICT N $N^{\circ} 2012-0733$ (Argentina) and Programa de Investigación de Excelencia Interdisciplinaria (PIEI-QUIM-BIO), Universidad de Talca, is deeply acknowledged.

\section{Author Contributions}

G.S.H. conducted the spectroscopic analysis of the resin samples and its fractions. M.L.V. and A.G. collected the samples and carried out the antifungal assays. V.R.O. analyzed all samples and performed the fractionation of the resins. A.G., M.L.V. and V.R.O. planned the antifungal assays.

\section{Conflicts of Interest}

The authors declare no conflict of interest.

\section{References and Notes}

1. Dell, B.; McComb, A.J. Plant resins-their formation, secretion and possible functions. Adv. Bot. Res. 1979, 6, 277-316.

2. Phillips, M.A.; Croteau R.B. Resin-based defences in conifers. Trends Plant Sci. 1999, 4, 184-190.

3. Franceschi, V.R.; Krokene, P.; Christiansen, E.; Krekling, T. Anatomical and chemical defenses of conifer bark against bark beetles and other pests. New Phytol. 2005, 167, 353-376.

4. Konno, K. Plant latex and other exudates as plant defense systems: Roles of various defence chemicals and proteins contained therein. Phytochemistry 2011, 72, 1510-1530.

5. Martin, D.; Tholl, D.; Gershenzon, J.; Bohlmann J. Methyl jasmonate induces traumatic resin ducts, terpenoid resin biosynthesis, and terpenoid accumulation in developing xylem of Norway spruce stems. Plant Physiol. 2002, 129, 1003-1018. 
6. Miller, B.; Madilao, L.L.; Ralph, S.; Bohlmann, J. Insect-induced conifer defense. White pine weevil and methyl jasmonate induce traumatic resinosis, de novo formed volatile emissions, and accumulation of terpenoid synthase and putative octadecanoid pathway transcripts in Sitka spruce. Plant Physiol. 2005, 137, 369-382.

7. Nagy, N.E.; Kroken, P.; Solheim, H. Anatomical-based defense responses of Scots pine (Pinus sylvestris) stems to two fungal pathogens. Tree Physiol. 2006, 26, 159-167.

8. Keeling, C.I.; Bohlmann, J. Resin diterpene acids in conifers. Phytochemistry 2006, 67, 2415-2423.

9. Yang, N.Y.; Liu, L.; Tao, W.W.; Duan, J.A.; Tian, L.J. Diterpenoids from Pinus massoniana resin and their cytotoxicity against A431 and A549 cells. Phytochemistry 2010, 71, 1528-1533.

10. Cox, R.E.; Yamamoto, S.; Otto, A.; Simoneit, B.R.T. Oxygenated di- and tricyclic diterpenoids of shouthern hemisphere conifers. Biochem. Syst. Ecol. 2007, 35, 342-362.

11. Jossang, J.; Bel-Kassaoui, H.; Jossang, A.; Seuleiman, M.; Nel, A. Quesnoin, a novel pentacyclic ent-diterpene from 55 million years old Oise amber. J. Org. Chem. 2008, 73, 412-417.

12. Lambert, J.B.; Wu, Y.; Santiago-Blay, J.A. Taxonomic and chemical relationships revealed by nuclear magnetic resonance spectra of plant exudates. J. Nat. Prod. 2005, 68, 635-648.

13. Lambert, J.B.; Kozminski, M.A.; Santiago-Blay, J.A. Distinctions among conifer exudates by proton magnetic resonance spectroscopy. J. Nat. Prod. 2007, 70, 1283-1294.

14. Otto, A.; Simoneit, B.R.T.; Rember, W.C. Resin compounds from the seed cones of three fossil conifer species from the Miocene Clarkia flora, Emerald Creek, Idaho, USA, and from related extant species. Rev. Palaeobot. Palynol. 2003, 126, 225-241.

15. Yamamoto, S.; Otto, A.; Simoneit B.R.T. Lignans in resin of Araucaria angustifolia by gas chromatography/mass spectrometry. J. Mass Spectrom. 2004, 39, 1337-1347.

16. Cool, L.G.; Power, A.B.; Zavarin, E. Variability of foliage terpenes of Fitzroya cupressoides. Biochem. Syst. Ecol. 1991, 19, 421-432.

17. Cool, L.G. Sesquiterpene alcohols from foliage of Fitzroya cupressoides. Phytochemistry 1996, 42, 1015-1019.

18. Olate, V.R.; Goikoetxeaundia Uzandizaga, O.; Schmeda-Hirschmann, G. Resin diterpenes from Austrocedrus chilensis. Molecules 2011, 16, 10653-10667.

19. Olate, V.R.; Soto, A. Schmeda-Hirschmann, G. Seasonal variation and resin composition in the Andean tree Austrocedrus chilensis. Molecules 2014, 19, 6489-6503.

20. Greslebin, A.G.; Hansen, E.M.; Sutton, W. Phytophthora austrocedrae sp. nov., a new species associated with Austrocedrus chilensis mortality in Patagonia (Argentina). Mycol. Res. 2007, 111, 308-316.

21. La Manna, L.; Matteucci, S.D.; Kitzberger, T. Abiotic factors related to the incidence of the Austrocedrus chilensis disease syndrome at a landscape scale. For. Ecol. Manag. 2008, 256, 1087-1095.

22. Greslebin, A.G.; Hansen, E.M. Pathogenicity of Phytophthora austrocedrae on Austrocedrus chilensis and its relation with mal del ciprés in Patagonia. Plant Pathol. 2010, 59, 604-612.

23. Bunny, F.; Tippett, J. Inhibitory effects of Pinus radiate and P. pinaster resin on growth of four Phytophthora species. Australas. Plant Pathol. 1988, 17, 14-16. 
24. Sravani, P.; Kiranmayee, Y.; Narasimha, S.; Reddy, V.S.; Asha, S.; Kumar R.B. In vitro experimental studies on selected natural gums and resins for their antimicrobial activity. Res. J. Pharm. Biol. Chem. Sci. 2014, 5, 154-172.

25. Brasier, C.; Webber, J. Sudden larch death. Nature 2010, 466, 824-825.

26. Davison, E.M.; Stukely, M.J.C.; Crane, C.E.; Tay, F.C.S. Invasion of phloem and xylem of woody stems and roots of Eucalyptus marginata and Pinus radiata by Phytophthora cinnamomi. Phytopathology 1994, 84, 335-340.

27. Durán, A.; Gryzenhout, M.; Slippers, B.; Ahumada, R.; Rotella, A.; Flores, F.; Wingfield, B.D.; Wingfield, M.J. Phytophthora pinifolia sp. nov. associated with a serious needle disease of Pinus radiata in Chile. Plant Path 2008, 57, 715-727.

28. Green, S.; Brasier, C.M.; Schlenzig, A.; McCracken, A.; MacAskill, G.A.; Wilson, M.; Webber, J.F. The destructive invasive pathogen Phytophthora lateralis found on Chamaecyparis lawsoniana across the UK. For. Pathol. 2012, 43, 19-28.

29. Than, D.J.; Hughes, K.J.D.; Boonhan, N.; Tomlinson, J.A.; Woodhall, J.W.; Bellgard, S.E. A TaqMan real-time PCR assay for the detection of Phytophthora "taxon Agathis" in soil, pathogen of Kauri in New Zealand. For. Pathol. 2013, 43, 324-330.

30. Krokene, P.; Nagy, N.E.; Krekling, T. Chapter 7. Traumatic resin ducts and polyphenolic parenchyma cells in conifers. In: Induced Plant Resistance to Herbivory; Schaller, A., Ed.; Springer Science + Business Media B.V.: Stuttgart, Germany, 2008; p. 480.

31. Kusumoto, N.; Ashitani, T.; Murayama, T.; Ogiyama, K.; Takahashi, K. Antifungal abietane-type diterpenes from the cones of Taxodium distichum Rich. J. Chem. Ecol. 2010, 36, 1381-1386.

32. Matsushita, Y.; Hwang, Y.H.; Sugamoto, K.; Matsui, T. Antimicrobial activity of heartwood components of sugi (Cryptomeria japonica) against several fungi and bacteria. J. Wood Sci. 2006, 52, 552-556.

33. Dictionary of Natural Products on DVD, 2015. Chapman and Hall.

34. Olivier, D.K.; Van Wyk, B.E. The major diterpenoids of the genus Arctopus (Apiaceae) with notes on their chemotaxonomic and medicinal significance. S. Afr. J. Bot. 2013, 85, 94-98.

35. Aranda, G.; El Kortbi, M.S.; Lallemand, J.Y.; Neuman, A.; Hammoumi, A.; Facon, I.; Azerad, R. Microbial transformation of diterpenes: Hydroxylation of sclareol, manool and derivatives by Mucor plumbeus. Tetrahedron 1991, 47, 8339-8350.

36. Asakawa, Y.; Noma, Y. 3.21-Biotransformation of di- and triterpenoids, steroids, and miscellaneous synthetic substrates. In Comprehensive Natural Products II; Liu, H.W., Mander, L., Eds.; Elsevier: Oxford, UK, 2010; Volume No. 3, pp. 893-965.

Sample Availability: Samples of the resins are available from the authors.

(C) 2015 by the authors; licensee MDPI, Basel, Switzerland. This article is an open access article distributed under the terms and conditions of the Creative Commons Attribution license (http://creativecommons.org/licenses/by/4.0/). 